\title{
Egg parasitism caused by Trichogramma spp. against maize stem borer, Chilo partellus.
}

\author{
R.U. Aziz ${ }^{1}$, S. Gaherwal ${ }^{1}$ * \\ ${ }^{1}$ Department of Zoology, Govt. Holkar Science College (DAVV), Indore, India \\ ${ }^{2 *}$ Department of Zoology, Govt. Holkar Science College (DAVV), Indore, India \\ *Corresponding author: psgaherwal@yahoo.com
}

Available online at: www.isroset.org

Received $11^{\text {th }}$ Sep 2017, Revised $14^{\text {th }}$ Sep 2017Accepted $19^{\text {th }}$ Oct 2017 , Online $30^{\text {th }}$ Oct 2017

\begin{abstract}
Present study was carried out to determine the numbers of egg batches and eggs per batch in the maize fields of selected sites of Indore. Moreover, discovery efficiency and parasitism efficiency was also determined. The result revealed that highest mean discovery efficiency rates of Trichogramma spp. was found from Mhow and was therefore having low parasitism per field and lowest mean discovery efficiency rate was recorded from Mangliya and was having high parasitism per field. There was generally a high variation in the numbers of egg batches and eggs per batch among the sites surveyed. The predominant parasitoid species was Trichogramma spp. This study showed that although egg parasitoid species diversity was higher, egg parasitism was considerably lower in selected sites of Indore.
\end{abstract}

Keywords: Trichogramma spp, discovery efficiency, egg parasitism. parasitism efficiency.

\section{INTRODUCTION}

Maize production is severely affected by number of biotic and abiotic factors. Among biotic factors stem borer (Chilo partellus, Swinhoe) is the most notorious and destructive pest. Maize (Zea mays, L.) is an important cereal crop of India. Because of pesticides use, problems have increased, thus it has stimulated renewed interest in biological control as a control method by itself or as a part of integrated pest control system. Among biological techniques, inundative releases of Trichogramma spp. have led to commercially successful programs against Chilo partellus Swinhoe) [1]. Inareas where Trichogramma spp. has been released continuously for years, has resulted in large ecological and economic benefits [2]. Trichogramma spp. is a tiny $(5 \mathrm{~mm}$ long) parasitoid, which attacks the eggs of its host. As a biological control agent, T. chilonis wasp are reared and released in the affected fields [3]. The larva (T. evanescens) goes through three developmental stages and pupate inside the host egg that cause host eggs turn black [4]. Trichogramma species have been reported from various hosts i.e., Acigona steniellus, Helicoverpa armigera, Chilo partellus, Chilo infuscatellus, and Emmalocera depressella [5]. Present study was designed to evaluate the parasitism caused by Trichogramma species on the host eggs of Chilo partellus. This study showed that although egg parasitoid species diversity was higher, egg parasitism was considerably lower in selected sites of Indore.

\section{RELATED WORK}

Trichogramma spp. as the pest egg parasitoid whose abundance decreases the population of stem borers at the very initial stage [6]. In the present study, the distribution of egg batches was regular to random, corroborating findings by [7-9]. Parasitoids locate borers by laying eggs into them while feeding inside the plant stems. When they will hatch, the larvae of theparasitic wasp will be feeding internally in the pest and kill it and then exit to spin cocoons [10].

\section{METHODOLOGY}

\section{Study Area:}

The present investigation was under taken in maize fields of Indoreregion. The selected areas of Indore region are as follows (1) Mangliya (2) Mhow (3) Depalpur (4) Sanwer.

\section{Experimental work:}

The collection of pest, Egg masses of Chilo partellus and the predators were done in maize fields and rearing and rest of the bio-assays were done in laboratory.

\section{Experimental insect:}

Chilo partellus (Swinhoe) (Maize stem borer) was selected for the present investigation. 


\section{Egg parasitism}

Parasitoids were calculated per egg mass by the method described by [11].

Three kinds of parasitization were calculated by for egg parasitoid:

(a) The ratio of Percent of eggs parasitized (individual egg batch), to all egg batches observed in the maize fields calculated as Mean egg parasitism per maize field.

(b) "Discovery" efficiency, the percentage of egg batches with parasitoids per field.

(c) The percentage of eggs parasitized within discovered egg batches, averaged over all egg batches per field called as "parasitism efficiency".

\section{RESULTS}

During 2015, In the selected regions of Indore where eggs were collected, overall mean number of egg batches were $1.09 \pm 0.1$ and $2.14 \pm 0.0$ per plant and the number of eggs per batch varied between $15.62 \pm 3.82$ and $33.41 \pm 2.15$ during 2015. The highest mean discovery efficiency rates were found from Mhow $(86.21 \pm 1.01)$ having a parasitism rate (Parasitism/ field (\%)) of $59.83 \pm 0.3$ and the lowest mean discovery efficiency rate were recorded from Mangliya as $61.02 \pm 0.34$ having a parasitism rate (Parasitism/ field (\%)) of $75.60 \pm 0.4$. The above mentioned result showed that the lowest discovery efficiency rates of parasitism in Mangliya region that is why maize stem borers were highest.

During 2016, In the selected regions of Indore where eggs were collected, overall mean numbers of egg batches were $1.32 \pm 0.0$ and $2.77 \pm 0.2 \mathrm{egg}$ batches per plant and the number of eggs per batch varied between $17.05 \pm 2.00$ and $38.07 \pm 1.88$. The highest mean discovery efficiency rates was found from Mhow $(88.09 \pm 0.11)$ having a parasitism rate (Parasitism/ field (\%)) of $51.48 \pm 0.0$ and lowest mean discovery efficiency rate was recorded from Mangliya as $63.41 \pm 0.28$ having a parasitism rate (Parasitism/ field (\%)) of $77.21 \pm 0.2$.

\section{DISCUSSION}

The highest mean discovery efficiency rates of Trichogramma spp. was found from Mhow and lowest mean discovery efficiency rate was recorded from Mangliya. The above mentioned result thus showed that because of the lowest discovery efficiency rates of parasitoids in Mangliya region, maize stem borers were highest.

Trichogramma spp. as the pest egg parasitoid whose abundance decreases the population of stem borers at the very initial stage [6]. In the present study, the distribution of egg batches was regular to random, corroborating findings by [7-9]. Parasitoids locate borers by laying eggs into them while feeding inside the plant stems. When they will hatch, the larvae of the parasitic wasp will be feeding internally in the pest and kill it and then exit to spin cocoons [10]. The above mentioned biologists are also in agreement with present study.

[12] also worked on Suitable Trichogramma spp. and dosage for the management of Chilo partellus (Swinhoe) in maize and found that the screening of various Trichogrammatids against Chilo partellus (Swinhoe) eggs revealed that Trichogramma chilonis Ishii gave significantly higher parasitism of $43.9 \%$. Egg parasitoids of the genus Trichogramma, including $T$. brassicae, have been successfully used to control mainly lepidopteran pests in biological control worldwide [13]. Thus the result is in agreement with the present investigation.

\section{CONCLUSION AND FUTURE SCOPE}

The highest mean discovery efficiency rates of trichogramma spp. was found from Mhow and lowest mean discovery efficiency rate was recorded from Mangliya. Therefore, because of the lowest discovery efficiency rates of parasitoids in Mangliya region, maize stem borers were highest. For sustainable low cost maize production, it is necessary to have a low cost technique of pest control. The control of pest by Trichogramma spp. is economical, more productive.

Table 1: Mean number of Chilo partellus egg batches per plant, eggs per batch, discovery efficiency and percentage egg parasitism due to Trichogramma spp. at the whorl stage of maize in four localities in Indore district of M.P. during 2015.

\begin{tabular}{|l|c|c|c|c|c|}
\hline \multicolumn{2}{|c|}{$\begin{array}{c}\text { Regions of } \\
\text { district } \text { Indore }\end{array}$} & Egg batches/plant & Egg/batch & $\begin{array}{c}\text { Discovery } \\
\text { efficiency (\%) }\end{array}$ & Parasitism/ field (\%) \\
\hline 1. & Mangliya & $2.14 \pm 0.0$ & $33.41 \pm 2.15$ & $61.02 \pm 0.34$ & $75.60 \pm 0.4$ \\
\hline 2. & Mhow & $1.09 \pm 0.1$ & $15.62 \pm 3.82$ & $86.21 \pm 1.01$ & $59.83 \pm 0.3$ \\
\hline 3. & Depalpur & $1.56 \pm 0.2$ & $18.47 \pm 3.22$ & $76.54 \pm 0.22$ & $67.01 \pm 0.2$ \\
\hline 4. & Sanwer & $2.01 \pm 0.0$ & $26.14 \pm 1.18$ & $67.99 \pm 1.35$ & $74.16 \pm 0.3$ \\
\hline
\end{tabular}


Table 2: : Mean number of Chilo partellus egg batches per plant, eggs per batch, discovery efficiency and percentage egg parasitism due to Trichogramma spp. at the whorl stage of maize in four localities in Indore district of M.P. during 2016.

\begin{tabular}{|l|c|c|c|c|c|}
\hline \multicolumn{2}{|c|}{$\begin{array}{c}\text { Regions of } \\
\text { district Indore }\end{array}$} & Egg batches/plant & Egg/batch & $\begin{array}{c}\text { Discovery } \\
\text { efficiency (\%) }\end{array}$ & Parasitism/field (\%) \\
\hline 1. & Mangliya & $2.77 \pm 0.2$ & $38.07 \pm 1.88$ & $63.41 \pm 0.28$ & $77.21 \pm 0.2$ \\
\hline 2. & Mhow & $1.32 \pm 0.0$ & $17.05 \pm 2.00$ & $88.09 \pm 0.11$ & $51.48 \pm 0.0$ \\
\hline 3. & Depalpur & $1.80 \pm 0.1$ & $22.94 \pm 3.01$ & $77.35 \pm 0.32$ & $63.93 \pm 0.1$ \\
\hline 4. & Sanwer & $1.99 \pm 0.2$ & $28.60 \pm 1.06$ & $69.17 \pm 0.21$ & $70.55 \pm 0.2$ \\
\hline
\end{tabular}

Figure 1: Mean number of Chilo partellus egg batches per plant, eggs per batch, discovery efficiency and percentage egg parasitism due to Trichogramma spp. at the whorl stage of maize in four localities in Indore district of M.P. during 2015.

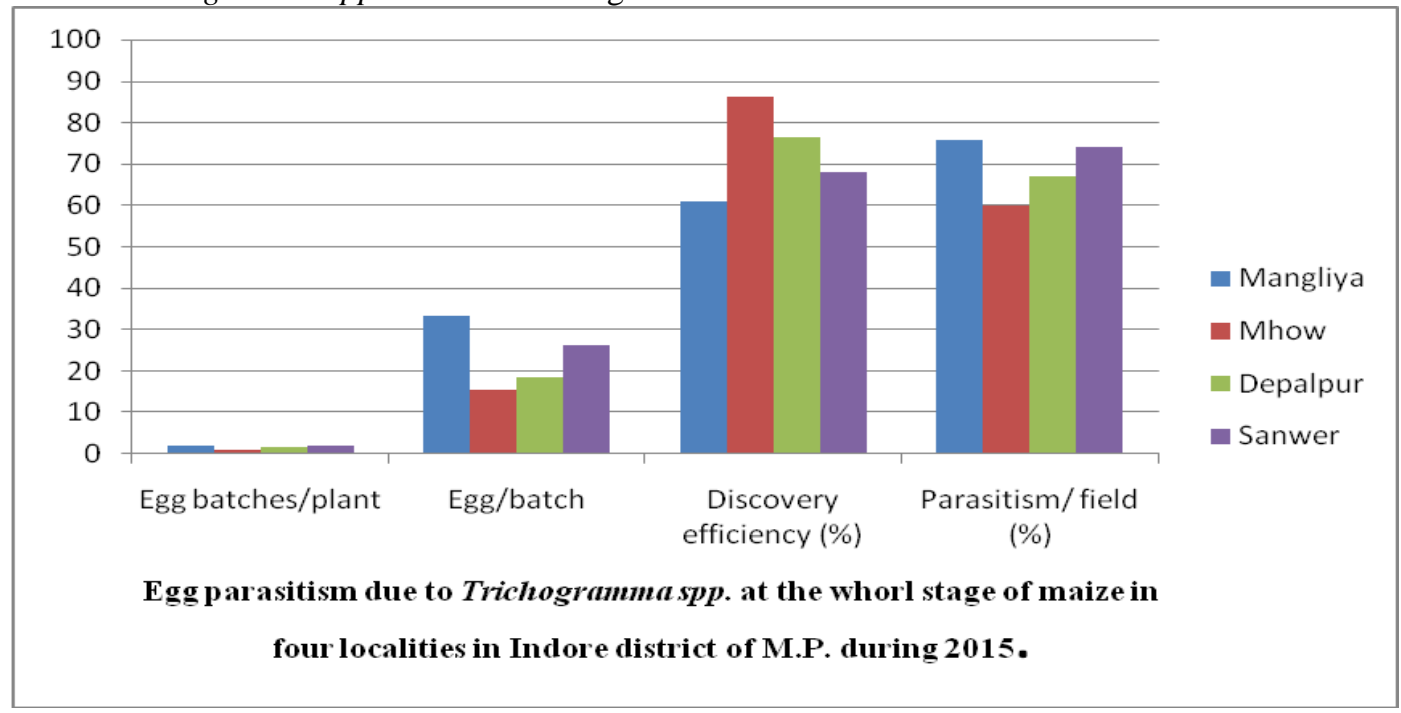

Figure 2: Mean number of Chilo partellus egg batches per plant, eggs per batch, discovery efficiency and percentage egg parasitism due to Trichogramma spp. at the whorl stage of maize in four localities in Indore district of M.P. during 2016.

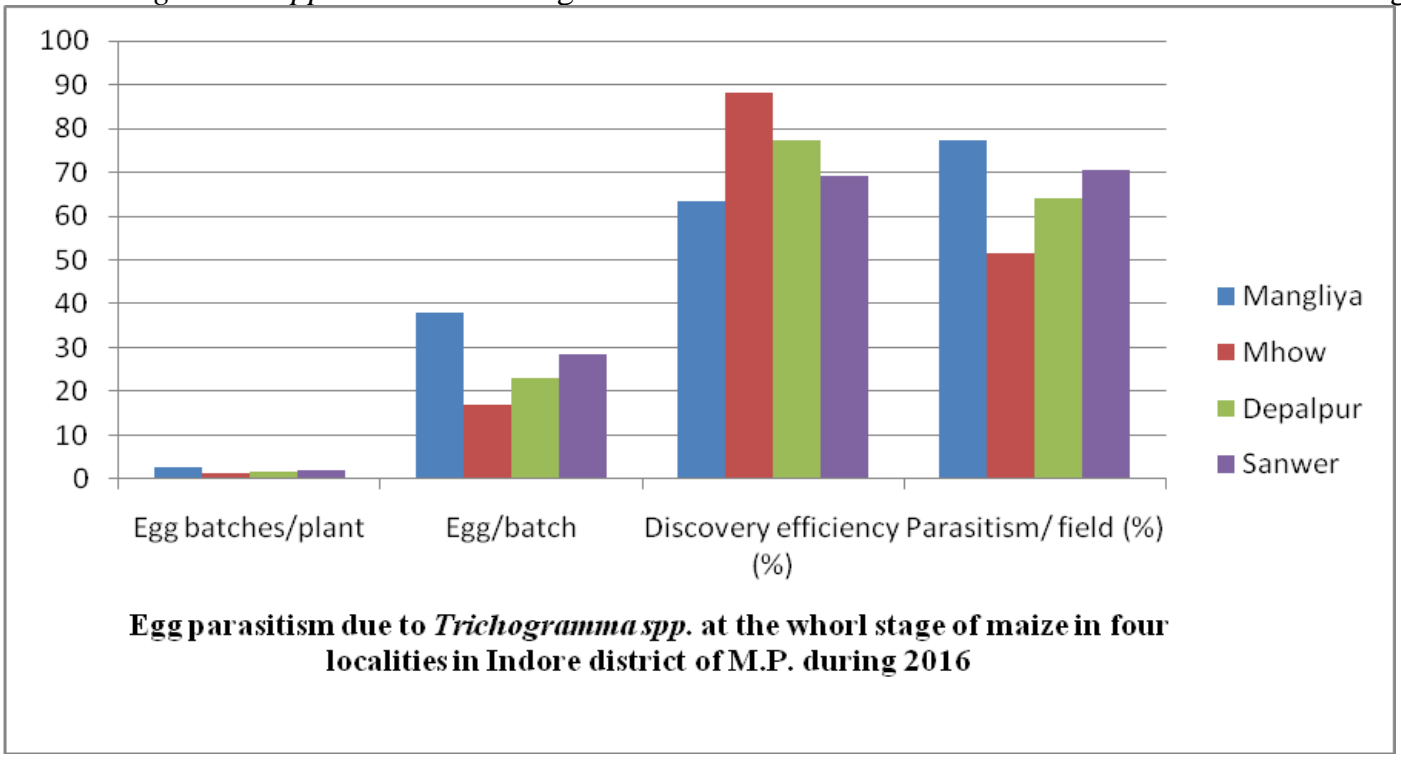




\section{REFERENCES}

[1]. F. Bigler, "Mass production of T. maidis Pint, et voeg and its field application against Ostrinia nubilalis Hbn",. In ndl. J App Entomol, vol.101, No.1-5, pp. 23-29, 1986.

[2]. F. Ullah, M. Shakur, H. Badshah, S. Ahmad, M. Amin, M. Zamin, "Efficacy of T. chilonis Ishii in comparison with two commonly used insecticides against sugarcane stem borer C. infuscatellus Snelless (Lepidoptera: Pyralidae)", J Anim Plant Sci, Vol., No.4 , pp.463-466, 2012.

[3]. Z.Y. Wan, K. He, J.Z. Zhao, D.R. Zhao, " implementation of integrated pest management in china", In " Integrated pest management in the global arena" (K.M. Maredia, D. bakous and D. Mote- Sanchez. EDS),pp. 197-207. CABI Publishing, Oxon, 2003.

[4]. S.A. Hassan, "Mass production and utilization of T. production of host Sitotroga cerealella", Entomophaga, Vol.26, No.4, pp. 339-347, 1981.

[5]. D. Hussain, H. Ali, M. Qasim, J. Khan, "Insecticidal susceptibility and effectiveness of T. chilonis as a parasitoids of tomato fruit borer, Helicoverpa armigera", Pak J Zoo, Vol. 47, No. 5, pp.1427-1432, 2015.

[6]. P. Abhilash, K. Rajmohana, "A new species of Gryon Haliday (Hymenoptera: Platygastridae) from India", Journal of Threatened Taxa, vol. 6, No.14, pp. 6711-6714, 2014.

[7]. F. Schulthess, O.A. Chabi, G. Geogen, "Seasonal fluctuation of Noctuid stem borer egg parasitism in southern benin with reference to Sesamia calamistis (Lepidoptera: Noctuidae) and Telonomus spp. (Hymenoptera : Schonidae) on maize", biocontrol science and technology, Vol.11, No. 1,pp. 745-757, 2001

[8]. R. Ndemah, F. Schulthes, S. Kories, C. Borgemeister, K.F. Cardwell, "Distribution, relative importance and effect of lepidopterous borers on maize fields in the forest zone and mid altitude of cameroon". Journal of economic entomology. Vol.94, No.9-10, pp.1434-1444, 2001

[9]. O. Chabi, A. Nolte, F. Schulthess, M.C. Borge, "Effects of grain legumes and cover crops on maize yield and plant damage by Busseola fusca (fuller) (Lepidoptera : Noctuidae) in the humid forest of southern cameron. Agriculture", Ecosystem and environment, Vol.108, No. 7, pp. 17-28, 2005.

[10]. P. Chindwada, W.A. Overholt, "Natural enemies of MSB on the high veld of zimbabwe”, African Entomology, Vol.9, No. 5, Pp. 67-75, 2001.

[11]. F. Bin, S. Vinson, "Efficacy assessment in egg parasitoids (Hymenoptera): proposal for a unified terminology. Trichogramma and other egg parasitoids San Antonio (TX), 23-27 September, 1990. Les Colloques no. 56. INRA, Paris, 1991.

[12]. H. Vijayakumar, S. K. Jalali, Prakash "Suitable Trichogramma sp. and dosage for the management of Chilo partellus (Swinhoe) in maize", Journal of Experimental Zoology, Vol. 18, No. 1, pp 253-256, 2015

[13]. S. Y. Li, D. E. Henderson, J. H. Meyer, "Selection of suitable Trichogramma species for potential control of the blackheaded fire worm infesting cranberries". Biocontrol, Vol.4, No.3, pp 244-248, 1994. 